U.S. DEPARTMENT OF THE INTERIOR

U.S. GEOLOGICAL SURVEY

\title{
FILTERED MAGNETIC ANOMALY MAPS OF MISSOURI
}

By T.G. Hildenbrand and R.P. Kucks 